\title{
The Socio-Demographic and Political Contexts and Legacies of the "Arab Spring" in North Africa
}

\author{
By Ken Roberts*
}

This paper sets the 2011 uprisings in their country contexts: the "demographic surge" throughout the region, which was being accompanied by youth migration into cities and increased enrolments in higher education, all amid job deficits in which higher education graduates had become the group at greatest risk of unemployment. The central argument in this paper is that relatively enduring "contexts" matter in accounting for 2011, but so do "events" and "recent developments". It is argued that young people's contexts, even in combination with "events" and "recent developments" such as the creation of new public spaces in old and new media, do not provide a full causal explanation of the events of 2011. The actors' political orientations need to be added. However, contexts become crucial in explaining "legacies", especially the political outcomes of the events of 2011. Survey evidence from the preceding and subsequent years permits the development of plausible explanations of how and why the Arab Spring erupted, spread, and led to different outcomes in different countries.

Keywords: Arab Spring, North Africa, Political mobilisation, Political parties, Youth.

\section{Introduction}

The "Arab Spring" has not led to the outcomes that were envisaged in 2011 by the "international community" (in practice the USA and its Western allies). The term "Arab Spring" was invented by this international community. It has never been widely used in the countries where the events occurred. In addition to naming the events, in 2011 the international community also decided that the events had been instigated by young people who were frustrated when facing the limited life chances that their countries offered and who were pro-democracy, looking westward for an alternative future. The European Union (EU) was an active player in this "framing" of the Arab Spring (Hyvonen 2014). As the protests spread from country to country, and as regimes fell in Tunisia then Egypt, it became possible to anticipate or at least hope that democracy would spread and take root throughout the region. In other words, the events of 2011 were to become part of an ongoing process that had started with the events of 1989 in Central and Eastern Europe.

We now know that the outcomes have differed from country to country. Tunisia in 2016 is more democratic but less secure for foreigners than in 2011. In Egypt the "reforms" have turned full circle. Elsewhere the protests

${ }^{*}$ Professor, University of Liverpool, UK. 
died down or were suppressed without any or following just modest constitutional reforms, as in Morocco. In Libya and Syria civil wars are ongoing. Islamic State (IS) has become another militant Islamist hub with which supporters in any country can now identify. If we (the international community) have learnt any lessons, one must be that we still cannot be certain about the long-term outcome in any country. However, we are now better informed and positioned to identify what caused the events of 2011 . The events were followed quickly by a spate of evidence-free or evidencelight theory construction about the causes as well as the likely outcomes to which the events of 2011 would lead. We now have the evidence that enables us to eliminate some postulated causes, then to focus on those that remain credible. We can thereby better understand why the outcomes up to now have varied so remarkably. This involves separating relatively enduring contexts from recent (in 2011) developments and unpredictable (as regards timing) sequences of events, adding the histories and current states of party political mobilisation and organisation in the relevant countries, amid which the motivations and worldviews of key actors in 2011 must be inserted.

Here the focus is on four North African countries - Morocco, Algeria, Tunisia and Egypt. These include the countries (Tunisia and Egypt) that led the uprisings in 2011, one country, far more typical of the Arab Spring, where there were modest reforms but no regime change (Morocco), and one country where there was no Arab Spring (Algeria). Libya rarely features in the following passages because of the paucity of information from inside the country both during the Gaddafi regime and subsequently on account of the civil wars.

Young people were high profile among the protestors in 2011, but this could have been because all the countries had (and still have) youthful populations (more on this below). The following passages interrogate whether the uprisings can be understood as generation wars, signalling the formation of new political generations (see Mannheim 1928/1952), and also whether the grievances that sparked the protests included impediments experienced by young people in their education to employment, and housing and family life stage transitions. If 2011 signalled the birth of new political generations, the Arab Spring is likely to go down in history as the beginning of long-term processes of change. Alternatively, it could be remembered as a spectacular set of events after which life returned to normal, much as before.

We begin by examining enduring contexts, starting with the "demographic surge", the expansion in the size of youth cohorts in the years preceding 2011, followed by trends in and young people's situations in 2011 as regards education-to-work, and family and housing life stage transitions. No-one claims that any one of these features of youth's condition in 2011 was the cause of the protests that erupted. However, in the spate of quickfire analysis that accompanied and followed the events of 2011, it was claimed that, in combination, the conditions had produced a "shared generational experience" (Murphy 2012) thereby creating a "new sociological generation" (Desrues 2012). Shared grievances were said to 
have united different factions of young people in a "movement of movements" (Singerman 2013). The initial slogans of the protestors in Egypt were "Bread, Freedom, Social Justice and Human Dignity" (Fahmy 2012). An accumulating and festering sense of indignity is said to have reached a point of explosion by the winter of 2010-2011. In Egypt, and possibly elsewhere, the incumbent regime is said to have lost middle class support by adopting neo-liberal policies which undermined middle class jobs, standards of living and lifestyles while creating a new class of regimelinked tycoon capitalists (Kandil 2012). These are among the claims that the following passages interrogate.

The analysis then moves on to the political motivations and goals of the protestors, and how and why the Arab Spring was able to spread so rapidly from country to country. We then reach tentative conclusions on the role of youth in these events, and the events' longer-term significance for young people and other citizens in North Africa.

We shall see in what follows that the North African countries differ from one another in many ways, but all the countries differ from the Middle-East states into which the Arab Spring spread but which rarely feature in the following analysis. The socio-economics and political dynamics of the Middle-East are different (see Althani 2012). Only Libya in North Africa could be described as having an economy based primarily on oil, gas and other minerals. Morocco still has a monarchy, but with far less power than the ruling houses in some Middle-East states. Relationships with Israel feature prominently in the politics of the Middle-East, as does the Sunni-Shia schism in Islam. None of these played a significant role in the Arab Spring in North Africa. This region has fewer of the "fault lines" that were liable to open following the events of 2011 in Middle-East countries (see Ayoob 2014).

\section{Contexts}

\section{The Demographic Surge}

This has been favoured by many commentators as at least contributing to the Arab Spring of 2011. A youth survey of 15-29 year olds by Egypt's Population Council in 1998 had noted the increasing size of cohorts in the child age groups. This was the result of declining infant and child mortality rates (Population Council 1998). This report noted that the swollen child cohorts would become swollen youth and young adult cohorts during the early- $21^{\text {st }}$ century which, the report argued, could be a demographic gift or disaster depending on whether jobs and housing were available. By the time of a second Egypt youth survey in 2009 the swollen cohorts had indeed become young people and young adults (Population Council 2011).

There has been exactly the same trend across the whole of North Africa. The region is currently experiencing the same demographic transition as happened in first-wave industrial countries a century and more ago. Birth 
rates in North Africa have now declined. Current cohorts of young adults are having fewer children than their own parents reared. This will create a demographic contraction in the child, then youth, then adult age groups, and North Africa will one day address the same ageing population demographic that exists today in economically advanced countries. However, the North African countries all currently have population pyramids with the numbers in each age group declining progressively from age 25 onwards.

Could this surge have triggered the Arab Spring? It was part of the context, but can it have been even a contributor? There are two grounds for doubt. First, all the North African countries have experienced steep and steady population growth for over 50 years. For example, Algeria's population has tripled since independence in 1962 (Hammouda 2010). Surging numbers in the youth cohorts are not new. Second, the progressive contraction in the size of age groups above age 25 is not due solely to higher infant and child mortality rates in the over 25 year old cohorts. Outward migration has also contributed. The outflow is continuing, so the countries are likely to retain population pyramids even alongside declining fertility rates. The destinations favoured by young emigrants from Egypt are Saudi Arabia and other Gulf states where salaries are much higher than at home. These destinations, especially the United Arab Emirates (UAE), are also attractive to young people from the rest of North Africa (see ASDA'A Burson-Martsteller 2015). All the countries share a common language (Arabic) with the Middle-East. However, French is also widely spoken in Morocco, Algeria and Tunisia (all former French colonies), so for young people from these countries an alternative destination is Europe. Spain and Italy are closest but France is as likely an ultimate destination. The UAE is Arab youth's most admired country, but it is followed closely by the USA, Canada, France and Germany ahead of Saudi Arabia and Turkey (ASDA'A Burson-Marsteller 2015).

\section{Labour Markets and Education}

The demographic surge was predicted to turn into a social and economic disaster unless the young people could be offered opportunities to progress to full adulthood, meaning that they needed routes towards then into adult jobs and access to independent housing.

General unemployment rates across North Africa were not particularly high in the years preceding or at the time of the Arab Spring (see Table 1). In Algeria and Morocco unemployment had been falling throughout the 1990s and 2000s, and in 2012 the rates were between $9 \%$ and $17 \%$ in all four countries. Youth unemployment rates were consistently higher: between 19\% and 28\% in Algeria, Egypt and Morocco but as high as $42 \%$ in Tunisia. Youth unemployment was much higher among females than males in Algeria and Egypt but not in Morocco, and no gender breakdown is available in the data for Tunisia. The latter country apart, in 2011-2012 youth unemployment rates were much higher across the Mediterranean in southern Europe. 
Table 1. Unemployment Rates (in percentages)

\begin{tabular}{|l|c|c|c|c|}
\hline $\begin{array}{l}\text { Unemployment } \\
\text { Rates }\end{array}$ & Algeria & Morocco & Tunisia & Egypt \\
\hline $1991-1995$ & 24 & 18 & $16(1996-2000)$ & 10 \\
\hline $2006-2009$ & 13 & 10 & 14 & 9 \\
\hline 2012 & 11 & 9 & 17 & 13 \\
\hline $\begin{array}{l}\text { Unemployment } \\
\text { Rates, 15-24 year } \\
\text { olds }\end{array}$ & $\mathbf{2 0 1 1}$ & $\mathbf{2 0 1 2}$ & $\mathbf{2 0 1 1}$ & $\mathbf{2 0 1 0}$ \\
\hline Males & 19 & 18 & & 15 \\
\hline Females & 38 & 19 & NA & 54 \\
\hline Total & 28 & 19 & 42 & 25 \\
\hline
\end{tabular}

Source: Tholen 2014.

Table 2. Labour Force Participation Rates (in percentages)

\begin{tabular}{|l|c|c|c|c|}
\hline $\begin{array}{l}\text { Labour Force } \\
\text { Participation Rates } \\
(\mathbf{1 5 +})\end{array}$ & Algeria & Morocco & Tunisia & Egypt \\
\hline $1991-1995$ & 51 & 53 & 48 & 50 \\
\hline $2006-2009$ & 58 & 52 & 48 & 48 \\
\hline $\begin{array}{l}\text { Females as } \\
\text { Percentage of } \\
\text { Labour Force }\end{array}$ & & & & \\
\hline $1991-1995$ & 25 & 25 & 23 & 26 \\
\hline $2006-2009$ & 30 & 26 & 27 & 24 \\
\hline
\end{tabular}

Source: Tholen 2014.

However, there are two features of North Africa's labour markets that depress the unemployment rates when these are measured in internationally standardised ways, as in Labour Force Surveys. First, there are low rates of labour market participation in all the countries, especially among women (see Table 2). North Africa and the Middle-East have lower rates of youth labour force participation than any other world regions (Roudi 2011). Second, significant proportions of employment in North Africa are in nonwaged (usually family) employment and informal jobs (without a contract) which may or may not pay a regular wage. Hammouda (2010) estimates that $36 \%$ of all employment in Algeria is informal. Egypt's 2009 youth survey provides a classification of types of youth employment that matches realities in the region more closely than international classifications (see Table 3). The most common types of employment for 15-29 year old males in 2009 were informal jobs with private employers that paid a regular wage $(44 \%)$ and similar jobs without a regular wage $(25 \%)$. For females, with much lower rates of labour market participation, the most common types of employment were with the government or a public enterprise $(38 \%)$ and informal jobs paying a regular wage in the private sector $(32 \%)$. Most women will accept employment outside their families only if working 
conditions are "decent" in an Arab Islamic context. Given the prevalence of informal private sector jobs, the outcome is chronic under-utilisation of female human capital. In Morocco women comprise $47 \%$ of tertiary students but account for just $26 \%$ of the workforce (Morikawa 2015).

Table 3. Types of Employment: 15-29 Year Olds in Egypt, 2009

\begin{tabular}{|l|c|c|}
\hline & Males & Females \\
\hline Government & 8 & 35 \\
\hline Public enterprise & 2 & 3 \\
\hline $\begin{array}{l}\text { Formal private regular } \\
\text { wage }\end{array}$ & 8 & 12 \\
\hline $\begin{array}{l}\text { Informal private regular } \\
\text { wage }\end{array}$ & 44 & 32 \\
\hline Irregular wage & 25 & 7 \\
\hline Unpaid family worker & 9 & 4 \\
\hline Self-employed/employer & 4 & 8 \\
\hline
\end{tabular}

Source: Population Council 2011.

\section{Housing and Family Transitions}

Throughout North Africa (as in many other parts of the world) marriage is considered essential in order to achieve full adulthood. Typical ages of marriage have been rising and now differ considerably from country to country. In Morocco the mean ages for first marriages in 2009 were 31 for men and 26 for women (Boudarbat and Ajbilou 2009). In Egypt in 2009 the most common ages of first marriages were 20-26 for men and 16-20 for women (Population Council, 2011). Young women in North Africa typically marry older men. In Egypt in 2009 92\% of married 15-29 year old women had older partners, and in $50 \%$ of marriages the age gap was six years or more.

Ideally, in all North African countries, marrying couples move into their own homes, but an alternative is to start married life with the husband's family. Very few young men (just 7\% in Egypt in 2009) said that they would accept living with in-laws. Young women in Egypt were more accepting, but only 54\% said that this arrangement would be acceptable (Population Council 2011). In 2009 the dwellings in which Egypt's 15-29 year olds were living typically contained more persons than rooms. Young men were often unable to marry because they did not have jobs that supplied incomes that would enable them to support independent households, or there was no suitable accommodation in their parents' homes, or their intended brides found this arrangement unacceptable. For young women, the shortage was of marriageable men of a similar age to themselves. Singerman (2007) argues that the cost of weddings (clothing, gifts and celebrations) is another reason why marriages are delayed. She calculates that in Egypt the typical total cost of a wedding has risen to around eleven times the average household's annual spending per capita. 
The combination of blocked progress from education to (acceptable) adult employment and transitions to independent households is said (by some commentators) to mean that throughout North Africa the youth life stage is often followed by an indefinitely prolonged "waithood" rather than adulthood (Dhillon and Yousef 2009). However, "waithood" is also a common life stage in Mediterranean Europe where it has continued to be customary for young people to remain in their parents' homes and delay marriage until their late-20s or even $30 \mathrm{~s}$, and this has been the context in which southern Europe's 20-somethings are unlikely to be offered permanent jobs and adult salaries (they do not need them) (see Cavalli 1997, Galland 1995, Golsch 2003). We can also note that in the USA Jim Arnett (2005) has identified a life stage which he calls "emerging adulthood" during which, he claims, young people voluntarily defer the onset of adult responsibilities. In America and Mediterranean Europe young people may (or may not) be able to feel confident that their "waithoods" will not extend into their 30s. Is it different in North Africa? The "bottom line" is surely that in the years preceding 2011, in 2011 itself, and subsequently up to now, North African youth have been able to secure livelihoods which have enabled them to make family and housing transitions. In 2011, 55\% of the demonstrators in Egypt were married (Brym et al. 2014).

\section{Actors' Motivations}

The preceding passages have sketched the wider contexts, but these alone are never a sufficient explanation of people's behaviour. Their own "definitions of the situation" and their own agency must always be part of an explanation, and this includes accounting for the eruptions of 2011. The mass protests were not about jobs or housing. Certainly the region's young people wanted more and better jobs and housing. They were also prodemocracy at least in principle (see ASDA'A Burson-Marsteller 2009). However, these were not the main reasons why the young people took to the streets. The demonstrators are angry and anti. Specifically, the protestors were united in being anti-government. All researchers and commentators have agreed on this. There was anger over police brutality, political and economic corruption, extremes of inequality, and governments' embrace of neo-liberal policies at least in the sense of withdrawal from funding basic services - housing, health care, education and pensions (see, for example, Fahmy 2012). The demonstrators wanted to change their countries' ruling regimes, or force the regimes to change their policies and methods. Only just over 10\% of Egypt's population aged over 14 took to the streets in 2011, but they had the support of another 70\% (Brym et al. 2014). There was anger, outrage, at the luxurious lifestyles at home and the wealth being stashed abroad by the countries' inter-connected political and business elites. There was anger at the brutal oppression of any dissent and at the abuse of power by police and other public officials. Corruption has a tendency to spread downwards then outwards and eventually pervades a 
society. These grievances are aptly illustrated by the event in Tunisia that sparked the protests of 2011 (see below).

It was Western politicians and media that decided that the North African mobilisations were pro-democracy. Western governments, and especially the USA's President Obama, aligned publicly with the protestors, though all the regimes had been valued partners of Western governments up to 2011. American NGOs offered advice, such as contained in Gene Sharp's books $(1994,2009)$. The recommended tactics had been tested in Belgrade in 2000 (the fall of Milosevic), used in the successful "colour revolutions" in Georgia and Ukraine in 2003-2005, then unsuccessfully in Azerbaijan and Belarus, but were reborn for use in Cairo in 2011 and again later that year with the Occupy movements. However, North Africa's events of 2011 were not really "made in America". They were incubated by conditions in the countries and ignited by the protestors' own motivations.

Surveys of Egypt's population in the 2000s had shown that popular support for democracy was at best ambivalent. According to $79 \%$ of a representative sample that was questioned, democracy was "very important", but when asked which party they were most likely to support in an election $73 \%$ chose the party of President Mubarak (Sika 2012). There were no signs in Egypt of any significant differences in values or political orientations between age groups (Rizzo et al. 2014). Throughout North Africa young people are less religious, more likely to be unemployed and have been more likely to protest than their elders, but they have been no more interested in politics or dissatisfied with the ruling regimes (Hoffman and Jamal, 2012). The events of 2011 do not appear to have signalled the birth of a new political generation (see Tessler and Miller-Gonzales 2015). The protestors wanted change, but the desire for change was neither new in 2011 nor age-specific. Moreover, protest marches and demonstrations had been recurrent in Tunis and Cairo throughout the 2000s. The Arab Spring would not have spread in the absence of "events" that were unpredictable, at least as regards timing.

\section{Events}

\section{The Spark}

On December $17^{\text {th }} 2010$ in Sidi Bouzid, a small town in Tunisia, Mohamed Bouazizi, a 26 year old street vendor, poured paint thinner over his left arm and set it alight when a policewoman instructed him to cease trading because he did not have a licence, or his licence was confiscated for some alleged infringement. There are different versions of what actually happened on December $17^{\text {th }}$. Was the policewoman hoping for a bribe? Was this an attempted suicide? We shall never know but we know for certain that Bouazizi died on January $4^{\text {th }} 2011$, which sparked protests in Tunis where the crowds of protestors refused to disperse despite facing gunfire and suffering fatalities. 


\section{Amplification}

As explained above, protests had been recurrent across North Africa throughout the 1990s and 2000s, but had always been dispersed using whatever force was necessary, as had happened to anti-regime mobilisations in Eastern Europe before 1989. In Tunis in 2011 the security forces declined to use the necessary force. Protestors were seen to be standing their ground. This was sufficient to encourage protestors to gather in Cairo's Tahrir Square. Then Tunisia's President Ben Ali fled the country and obtained refuge in Saudi Arabia. Ben Ali was hoping to return before long, but following his exit from Tunis Egypt's military hierarchy decided that President Mubarak was dispensable. The floodgates were then open for protests across the remainder of North Africa (except Algeria) and the rest of the Middle-East.

\section{Spreading the Flames: Old and New Media}

Some commentators have highlighted the role of mobile phones and social media in drawing the crowds of protestors across North Africa (see Cole 2014, Shahine 2011), and likewise in England's city riots in 2011, in the rapid spread of the Indignados protests in Spain, and the subsequent Occupy movement (all in 2011). However, the 1981 riots in England and the 1989 revolutions in Eastern Europe were unaided by new media. In 2011 new media were instrumental, though in Egypt, for example, at that time only around a quarter of households were connected to the internet, less than $6 \%$ of the population was using Facebook, and although over three-quarters of urban youth had mobile telephones, these were not necessarily smartphones (see Nouiehad and Warren 2013, Population Council 2011). Robert Brym and his colleagues (2014) have used Gallup Poll data to show that using social media did increase the likelihood of the users becoming street demonstrators, but this was far less important than political grievances, existing non-virtual social networks and structural availability. Demonstrators with smartphones could upload images to YouTube from where they were picked up by older media. Al-Jazeera was probably crucial in creating a public space for protestors' voices (Noueihed and Warren 2013). That said, the mobilisations would very likely have occurred in the absence of any new media.

A more plausible explanation of all the contagions in 2011 is the apparent success of the first protests. It was the apparent success of the protests in Tunis and Cairo that unleashed the Arab Spring across North Africa and throughout the Middle East. Apparently successful models to mimic also applied in spread of urban riots throughout England in 1981 and again in 2011. In 1981 young people in Brixton were shown (on television) to be holding their own in street battles with the police. Very quickly there were similar confrontations in other parts of London and in other major cities (see Benyon 1984, Scarman 1981). In 2011 televised unobstructed looting in Tottenham (north London) sparked similar riots in other parts of 
the city and then throughout the country (The Guardian/London School of Economics 2012). Likewise in 1989, the installation of a non-communist government in Poland following the June $4^{\text {th }}$ election demonstrated that change was possible, and before long citizens were mobilising in the German Democratic Republic, in Czechoslovakia, then in the East Balkans, and then in the West Balkans (see Roberts 2012).

Smartphones and internet use have spread rapidly among Arab youth since 2011. By $201577 \%$ of 18-24 year olds in 16 Arab majority countries had smartphones, and $82 \%$ were daily internet users (ASDA'A BursonMarsteller, 2015). Does this make youth mobilisations more likely than in 2011? It is certainly likely that these new communication technologies will be used more extensively and intensely in any future mobilisations.

The new media were probably most influential in North Africa prior to 2011 in assisting the formation of networks of civil society associations. For example, in Egypt the Egyptian Movement for Change (popularly known as Kefaya) was created in 2004 to combat President Mubarak's bid for a further term in office and the grooming of his son as successor. The "information age generation" was by then forming a series of protest groups. The most influential in Egypt was probably the April 6 Movement which was launched by four young people on Facebook in 2008 in support of a planned strike by textile workers (Fahmy 2012). There was a similar upsurge of extra-institutional political activity in Tunisia (Chomiak 2011). These developments, combined with multi-channel satellite television, were probably especially crucial in facilitating private horizontal communications, in further eroding the regimes' previous control of flows of information and ideas (Hafez 2013), and in enabling "movements of movements" to coalesce rapidly in 2011 (Singerman 2013). However, to repeat and as Chomiak (2011) has also noted, there were similar developments, unaided by any new media, throughout Eastern Europe in the decades preceding 1989.

\section{Legacies}

\section{Politics and Government}

The immediate outcomes of the events of 2011 differed from country to country, as might have been expected given that the countries differed from one another at the beginning of the year, not least in the character of their political systems. As Skalli (2013) argues, if we are to fully understand what happened in 2011, we need to disaggregate the countries, places within countries, and youth themselves need to be disaggregated. During 2011 there was regime change in Egypt, Libya (with crucial assistance from NATO forces) and Tunisia (and also in Yemen). None of the changes of regime can be described as revolutionary. None led to economic or social transformations: 2011 was not a repeat of 1989. Elsewhere, as in Morocco (see Layachi 2015), the regimes survived having conceded modest reforms, 
dispersed the protestors, or just waited until the protestors dwindled, except in Libya (see Vandevalle 2010) and Syria where the initial confrontations led to civil wars. Western donors who had been supporting civil society and pro-democracy groups found their resources being sucked into the local socio-political dynamics (Staeheli and Nagel 2012). The flows of ideas and practices across transnational protest networks (Porta and Mattoni 2014) suffered the same fate. Egypt underwent double regime change. Elections in 2011-2012 made the Freedom and Justice Party, the political arm of the Moslem Brotherhood, the largest party in the parliament and created a Moslem Brotherhood president, Mohamed Morsi. The parliament was subsequently dissolved by the judiciary, and the president and his government were deposed in a military coup in 2013. The Moslem Brotherhood became a proscribed organisation and (ex) General Sisi was elected president in 2014 (see Osman 2013 for events up to that year). The unity of "the people" during the protests at the beginning of 2011 was shortlived. There were numerous "voices in the Square" in 2011.The protestors were united only in what they were against (the government). There was no consensus on what or who they were for (see Steavenson 2015). This is why during and following the protests there were so many attempts to "frame the debate" (see AlMaghlouth et al. 2015). In 2011 the protests were contested rather than crafted by lead instigators, and the outcomes have been, and are still, contested and open-ended rather than linear (Asselburg and Wimmen 2016). People whose ideal polity would be a Western-type democracy can simultaneously believe that, at present, an authoritarian ruler is best for their own countries. Shahine (2011) argues that in Egypt, by 2011, "stability" meant "no prospects" and "no progress" rather than "security", but evaluations appear to have changed (see below) since the Arab Spring developed into civil wars in Libya and Syria.

Western-type democracies need to be built, and this usually takes decades. Also, the context must be favourable. Over 50 years ago Seymour Martin Lipset (1960), the American political sociologist, argued that Western-type democracies would work satisfactorily only if defeated parties found rule by their opponents acceptable. Democracy itself was supposed to foster this outcome because all parties that sought power would be obliged to position themselves on a common middle ground. Maybe this would be the outcome if democracy was given a long-run in North Africa but this is unlikely to happen in most of the countries. Even Tunisia's currently functioning democracy may prove too fragile to last. At present all the North African societies are deeply divided, which appears to foster split minds on the best form of government. Around a half of the populations in North Africa (but only a half) consider that instilling religious belief is "most important" in the upbringing of a child. On the Mediterranean's northern shores less than a fifth of the populations believe likewise (Anna Lindh Foundation 2014). Surveys in 2009 found that no more than half of respondents across North Africa and the Middle-East (41\% in Egypt) supported freedom of speech, assembly and religion (Brym et al. 2014). 
North African societies are split into imperfectly coinciding divisions between the rural and the urban, the traditional and the modern, and the religious and the secular. We can illustrate these divisions from the results of the 2009 youth survey of 15-29 year olds in Egypt. 55\% of males and $70 \%$ of females said that they prayed more than once a day. $90 \%$ of $25-29$ year old females, $85 \%$ of $18-24$ year olds and $79 \%$ of $15-17$ year olds had been circumcised. This practice has been illegal in Egypt since 2007 but it still happens. $70 \%$ of males and $58 \%$ of females argued that female circumcision was "necessary". $71 \%$ of the males and $49 \%$ of females said that a sister should always obey her brother, even a younger brother (Population Council 2011). These views and practices are anathema to many modern Egyptians. In some North Africa and Middle-East countries there are additional divisions between religious communities, regions and even tribal groups. In recent decades there has been growth in the size of the middle classes in North Africa's major cities (Osman 2012). At the same time, there has been growth in Islamist political activity (Haynes 2013). The societies have become more, not less divided, and this applies among young people as much if not more so than among their elders.

Rogerson (2012) argues that democracy has a different meaning in Islamic than in Western cultures. Islamic democracy, he claims, means not just elections but also continuous dialogue between rulers and all interest groups. This claim is unconvincing. The ideas are neither particularly nor specifically Islamic. One party "democratic" communist rule has always been justified in these terms. Turkey is a modern (Western-type) democratic Moslem country.

It may have been the case, as indicated in Honwana's ethnography in Tunisia, that the young cyber-activists and street demonstrators in 2011 were not interested in voting in the elections to which their protests led (Honwana 2013). This also applied to Spain's Indignados whose protests followed the Arab Spring in 2011 (Castells 2012, Castells et al. 2012). The Indignados' preferred forms of participation were by using social media and mass meetings which worked towards a consensus. However, it was also the case that neither the Indignados nor the North African protestors had developed policies with which, or elevated leaders with whom, to campaign for election in 2011 and 2012, though by 2015 a new left-wing, antiausterity party, Podemos, had become a serious contender for power in Spain. In all the North African countries where elections were held in 2011 or 2012 (Egypt, Libya, Tunisia and Morocco) the winner was an Islamic party, though by 2014 further elections in Tunisia had resulted in a secular president (with a background in the pre-2011 regime) and a parliament in which a secular party (Nidaa Tounes) held the largest number of seats. There was no Arab Spring in Algeria which had been under military rule since independence in 1962 (see Aghrout and Zoubir 2015). Experiments with local democracy in Algeria at the end of the 1980s were abandoned when Islamic parties developed a winning track record (Sueur 2010).

Modern youth in North Africa may idealise Western-type democracy but realise that their best protection against Islamic rule in the short-term is 
a secular, non-democratic authoritarian ruler. Perhaps regime change (where this happened in 2011 or 2012) has led to progress, meaning not democratisation but in terms of the protestors' own aims: less expropriation of resources by political and business elites, less corruption within state agencies, and less repression of all dissent in some countries (Morocco and Tunisia, but not Egypt or Algeria). In all the countries the events of 2011 accelerated the replacement of older with younger cohorts of political leaders, but this has been traditional politics throughout Africa (Muna et al. 2014). The main struggles are between younger and older cohorts and are about power rather than policies.

Parties that compete for power in stable democracies cannot be formed instantly. Such parties will not arise from pre-existing divisions and interest groups. This leads to political fragmentation. Successful parties need to build blocs of support and thereby organise their societies (see Leon et al. 2015). This means appealing to and speaking for a variety of groups. Tugal (2015) explains how this has been achieved over many decades in Turkey whereas Egypt's Moslem Brotherhood simply claimed to represent all Moslems then found that this was not the case. In Tunisia the necessary blocs may have been built successfully before and following 2011 by Ennahda (the moderate Islamic party that led the government from 20112014) and its successor in power, the secular Nidaa Tounes. Rule led by either of these parties has proved acceptable to the other. However, neither party is acceptable to the country's militant Islamists. Also, political activity, even voting in Tunisia's 2014 election, was dominated by the university educated (Berman and Nugent 2015). Neither of the major parties has been able to mobilise the country's less educated majority who populate the country's poorer regions. Tunisia's transition to a still fragile democracy has depended on exceptional (in North Africa) favourable conditions (see Antonakis-Nashif 2016).

\section{Young People's Views}

It is easier to generalise about how young people's attitudes have been affected by the events of 2011 and their aftermath. Since 2008 the ASDA'A Burson-Marsteller Arab Youth Surveys have monitored changes in the attitudes of 18-24 year olds across North Africa and the Middle East. In 2009 young people's top priority was to live in a democratic country, and the desire for democracy strengthened during the Arab Spring. Then by 2012 and 2013 fair pay and home ownership had become the top priorities and civil unrest had joined lack of democracy as a lesser concern. In 2014 civil unrest was a greater concern than lack of democracy. Then by 2015 there had been a decline to just $15 \%$ in the proportion of Arab youth who believed that lack of democracy was the greatest problem facing their countries. Their main concerns were unemployment (81\%) and the growing influence of IS (73\%). Possibly the main legacy of 2011 has been the creation of this additional umbrella organisation with bases in Syria and Iraq, and also in Libya, the countries in which post-2011 civil wars are 
ongoing. That said, in $201557 \%$ of Arab youth felt that their own countries were headed in the right direction (ASDA'A Burson-Marsteller 2009, 2011, 2012, 2013, 2014, 2015).

\section{Conclusions}

The above passages have shown that it becomes possible to "explain" the Arab Spring if we separate longer-standing contexts, recent developments, events that were unpredictable (at least in timing), add the key actors' orientations and motivations, and distinguish different legacies in different countries. That said, it is probably still too soon to offer a final summary of what was achieved by the Arab Spring. Where there has been no step towards democracy, there has not been continuity. All rulers are said to have been made aware that they can be toppled by those that they rule (Cavatorta 2015). Maybe they have also learnt that they will not be toppled provided they can retain the support of a country's security forces.

None of the countries has become a Western-type democracy. However, Morocco and Tunisia have arguably become more democratic (Perkins 2014). Some powers have been transferred from the king to the parliament in Morocco. The composition of governments in Tunisia is now determined by the result of elections. It is only in these two countries (not in Algeria, Libya or Egypt) where new space has been created for citizens to express their views and mobilise. During a brief time window there was similar space in Egypt which was used most effectively by Islamic groups. Everywhere it was Islamic groups that could use existing organisations that were the first to be able to use this space, but since then in Tunisia new secular political parties have been able to form. Given more time, this might have happened in Egypt, but the Moslem Brotherhoods' opponents appear to have preferred a quick return to power by a military backed regime. The regimes in Morocco and Tunisia appear to be less repressive. Maybe all the North African regimes, Libya excepted, are now less prone to syphon their countries' resources into private bank accounts, and public officials (including police) may have become less corrupt. Police forces may have become less brutal. In other words, there have been mixed but generally positive outcomes in terms of the protestors' own objectives.

However, there has been no progress anywhere in improving young people's employment and housing prospects (see Organisation for Economic Cooperation and Development 2015). The events of 2011 damaged all the countries' economies. Tourism was always a casualty having become an increasingly important source of jobs and foreign currency. It is still too early to give a final verdict on whether or where the events of 2011 were the start of longer-term changes and where they were simply events, outbursts of protest which happen periodically in the histories of countries where little else changes in young people's or other citizens' circumstances. At present it looks highly unlikely that 2011 signalled the birth of a new political generation that will be a force for 
continuous change as its members become majorities of citizens and politicians (see Tessler and Miller-Gonzales 2015). On this matter, it is not too soon to tell.

\section{Acknowledgments}

This paper has been prepared within the research project FP7-SSH2013-2 SAHWA: empowering the young generation; towards a new social contract in South and East Mediterranean countries.

\section{References}

Aghrout A and Zoubir YH (2015) Algeria: reforms without change? In YH Zoubir, G White (Eds) North African Politics: Change and Continuity, 145-155. London: Routledge.

AlMaghlouth N, Arvanitis R, Cointet J-P, Hanafi S (2015) Who frames the debate on the Arab uprisings? Analysis of Arabic, English, and French academic scholarship. International Sociology 30: 418-441.

Althani MAJ (2012) The Arab Spring and the Gulf States: Time to Embrace Change. London: Profile Books.

Anna Lindh Foundation (2014) The Anna Lindh Report 2014: Intercultural Trends and Social Change in the Euro-Mediterranean Region. Cairo: Anna Lindh Foundation.

Antonakis-Nashif A (2016) Contested transformation: mobilized publics in Tunisia between compliance and protest. Mediterranean Politics 21: 128-149.

Arnett JJ (2005) Emerging Adulthood: The Winding Road from Late-Teens through the Twenties. Oxford: Oxford University Press.

ASDA'A Burson-Marsteller (2009) Second Annual ASDA'A Burson-Marsteller Arab Youth Survey. Dubai: ASDA'A Burson-Marsteller.

ASDA'A Burson-Marsteller (2011) Third Annual ASDA'A Burson-Marsteller Arab Youth Survey. Dubai: ASDA'A Burson-Marsteller.

ASDA'A Burson-Marsteller (2012) After the Arab Spring: ASDA'A BursonMarsteller Arab Youth Survey 2012. Dubai: ASDA'A Burson-Marsteller.

ASDA'A Burson-Marsteller (2013) Our Best Days are Ahead of Us: ASDA'A Burson-Marsteller Arab Youth Survey 2013. Dubai: ASDA'A BursonMarsteller.

ASDA'A Burson-Marsteller (2014) ASDA'A Burson-Marsteller Arab Youth Survey 2014. Dubai: ASDA'A Burson-Marsteller.

ASDA'A Burson-Marsteller (2015) Arab Youth Survey 2015. Riyadh: ASDA'A Burson-Marsteller.

Assaad R, Barsoum G (2009) "Rising expectations and diminishing opportunities for Egypt's young". In N Dhillon, T Yousef (Eds) Generation in Waiting: The Unfulfilled Promise of Young People in the Middle East, 67-94. Washington DC: Brookings Institute Press.

Asselburg M, Wimmen H (2016) Dynamics of transformation, elite change and new social mobilization in the Arab world. Mediterranean Politics 21: 1-22.

Ayoob M (2014) Will the Middle East Implode? Cambridge: Polity.

Barbagli B (1982) Educating for Unemployment. New York: Columbia University Press. 
Berman CE, Nugent ER (2015) Defining Political Choices: Tunisia's Second Democratic Elections from the Ground Up, Analysis Paper 38. Washington DC: Center for Middle East Policy, Brookings Institution.

Bernadi F (2003) Returns to educational performance at entry into the Italian labour market. European Sociological Review 19: 25-40.

Benyon J (Ed) (1984) Scarman and After. Oxford: Pergamon.

Bogaert K, Emperador M (2011) Imagining the state through social protest: state reformation and the mobilizations of unemployed graduates in Morocco. Mediterranean Politics 16: 241-259.

Boudarbat B, Ajbilou A (2009) Moroccan youth in an era of volatile growth, urbanization and poverty. In $\mathrm{N}$ Dhillon, $\mathrm{T}$ Yousef (Eds) Generation in Waiting: The Unfulfilled Promise of Young People in the Middle East, 166188. Washington DC: Brookings Institute Press.

Boughzala M (2013) Youth Employment and Economic Transition in Tunisia, Global Economy and Development Working Paper 57. Washington DC: Brookings Institution.

Brownlee J, Masoud T, Reynolds A (2015) The Arab Spring: Pathways of Repression and Reform. New York: Oxford University Press.

Brym R, Godbout M, Hoffbauer A, Menard G, Zhang TH (2014) Social media in the 2001 Egyptian uprising. British Journal of Sociology 65: 266-292

Castells M (2012) Networks of Outrage and Hope: Social Movements in the Internet Age. Cambridge: Polity Press.

Castells M, Caraca J, Cardoso G (2012) The cultures of the economic crisis: an introduction. In M Castells, J Caraca, G Cardoso (Eds) Aftermath: The Cultures of the Economic Crisis, 1-14. Oxford: Oxford University Press.

Cavalli A (1997) The delayed entry into adulthood: is it good or bad for society? In JM Pais, L Chisholm (Eds) Jouvens em Mundanca. Lisbon: Instituto de Ciencias Socias, University of Lisbon.

Cavatorta F (2015) Non democratic change... and yet no authoritarian continuity: the inter-paradigm debate and North Africa after the uprisings. British Journal of Middle Eastern Studies 42: 135-145.

Chomiak L (2011) The making of a revolution in Tunisia. Middle East Law and Governance 3: 68-83.

Cole J (2014) The New Arabs: How the Millennial Generation is Changing the Middle East. New York: Simon and Schuster.

Dafflon D (2009) Youth in Russia - The Portrait of a Generation in Transition. Biel: Swiss Academy for Development.

Desrues T (2012) Moroccan youth and the forming of a new generation: social change, collective action and political activism. Mediterranean Politics 17: 23-40.

Dhillon N, Salehi-Istahani D, Yousef T, Fahmy A, Kraetsch M (2009) Missed by the Boom, Hurt by the Bust: Making Markets Work for Young People in the Middle East. Dubai: Wolfensohn Center for Development.

Dhillon N, Yousef T (Eds) (2009) Generation in Waiting: The Unfulfilled Promise of Young People in the Middle East. Washington DC: Brookings Institute Press.

Fahmy H (2012) An initial perspective on "The Winter of Discontent": the root causes of the Egyptian revolution. Social Research 79: 349-376.

Galland O (1995) Introduction: what is youth? In A Cavalli, O Galland (Eds) Youth in Europe, 1-6. London: Pinter.

Golsch K (2003) Employment flexibility in Spain and its impact on transitions to adulthood. Work, Employment and Society 17: 691-718. 
Hafez BN (2013) New social movements and the Egyptian Spring: a comparative analysis between the April 6 Movement and the Revolutionary Socialists. Perspectives on Global Development and Technology 12: 98-113.

Hammouda N-E (2010) Young, Educated and Unemployed: A Review of Algeria's Labour Market Reality. Geneva: Bureau International du Travail.

Hansen KT (2008) Introduction: youth and the city. In KT Hansen, AL Dalsgaard (Eds) Youth and the City in the Global South, 3-23. Bloomington: Indiana University Press.

Haynes J (2013) The "Arab Uprising", Islamists and democratization. Mediterranean Politics 18: 170-188.

Hoffman M, Jamal A (2012) The youth and the Arab Spring: cohort differences and similarities. Middle East Law and Governance 4: 168-188.

Honwana A (2013) Youth and Revolution in Tunisia. London: Zed Books.

Hyvonen A-E (2014) From event to process: the EU and the Arab Spring. In D della Porta, A Mattoni (Eds) Spreading Protest: Social Movements in Times of Crisis, 91-116. Colchester: Ecpr press.

Kandil H (2012) Why did the Egyptian middle class march to Tahrir Square? Mediterranean Politics 17: 197-215.

Kandil H (2015) Inside the Brotherhood. Cambridge: Polity.

Layachi A (2015) Morocco: keeping the revolution at bay with an enhanced status quo. In YH Zoubir, G White (Eds) North African Politics: Change and Continuity, 210-224. London: Routledge.

Leon C de, Desai M, Tugal C (2015) Introduction. Political articulation: the structured creativity of parties. In C de Leon, M Desai, C Tugal (Eds) Building Blocs: How Parties Organize Society, 1-35. Stanford: Stanford University Press.

Lillis J (2010a) Citizens in Kazakhstan are high on Nazarbayev, tepid on democratization. Retrieved from www.eurasianet.org, posted 26 May 2010. [Accessed May 26, 2010].

Lillis J (2010b) Nazarbayev adored as Kazakhs eye Kyrgyz strife with suspicion. Retrieved from www.eurasianet.org, posted 17 August 2010. [Accessed August 17, 2010].

Lipset SM (1960) Political Man. New York: Doubleday.

Mannheim K (1928/1952) The problem of generations. Essays on the Sociology of Knowledge. London: Routledge.

Mellor N (2014) Who represents the revolutionaries? Examples from the Egyptian Revolution 2011. Mediterranean Politics 19: 82-98.

Morikawa Y (2015) The Opportunities and Challenges for Female Labor Force Participation in Morocco. Global Economy and Development Working Paper 86. Washington DC: Brookings Institution.

Muna WK, Stanton A, Mwau DM (2014) Deconstructing intergenerational politics between "Young Turks" and "Old Guards" in Africa: an exploration of the perception of leadership and governance in Kenya. Journal of Youth Studies 17: 1378-1394.

Murphy EC (2012) Problematizing Arab youth: generational narratives of systemic failure. Mediterranean Politics 17: 5-22.

Noueihed L, Warren A (2013) The Battle for the Arab Spring: Revolution, Counter-Revolution and the Making of a New Era. New Haven: Yale University Press.

O'Boyle L (1970) The problem of an excess of educated men in Western Europe, 1800-1850. Journal of Modern History 42: 471-495. 
Organisation for Economic Cooperation and Development (2015) Youth in the MENA Region: How to Bring Them In. Paris: Organisation for Economic Cooperation and Development.

Osman T (2012) Young Egyptians: their society and future. Social Research 79: 299-322.

Osman T (2013) Egypt on the Brink: From Nasser to the Muslim Brotherhood. New Haven: Yale University Press.

Perkins K (2014) A History of Modern Tunisia, Second Edition. New York: Cambridge University Press.

Population Council (1998) Adolescence and Social Change in Egypt. Cairo: Population Council.

Population Council (2011) Survey of Young People in Egypt. Cairo: Population Council.

Porta D della, Mattoni A (2014) Patterns of diffusion and the transnational dimension of protests in the movements of the crisis: an introduction. In D Porta della, A Mattoni (Eds) Spreading Protest: Social Movements in Times of Crisis, 1-18. Colchester: Ecpr press.

Rizzo H, Abdel-Latif A-H, El-Moghazy A (2014) The road to revolution and Egyptian youth: findings from the Value Surveys. Paper presented at International Sociological Association World Congress, Yokohama.

Roberts K (2012) 1989: so hard to remember and so easy to forget. In C Leccardi, C Feixa, S Kovacheva, H Reiter, T Sekulic (Eds) 1989 - Young People and Social Change After the Fall of the Berlin Wall. Strasbourg: Council of Europe.

Rogerson B (2012) North Africa: A History from the Mediterranean Shore to the Sahara. London: Duckworth.

Roudi F (2011) Youth Population Employment in the Middle East and North Africa. Washington DC: Population Reference Bureau.

Roudi F (2011) Youth Population Employment in the Middle East and North Africa. Washington DC: Population Reference Bureau.

Salehi-Isfahani D, Dhillon N (2008) Stalled Youth Transitions in the Middle East: A Framework for Policy Reform, Middle East Youth Initiative Working Paper. Dubai: Wolfensohn Centre for Development.

Scarman L (1981) The Brixton Disorders, 10-12 April 1981, Cmd 8427. London: HMSO.

Shahine SH (2011) Youth and the revolution in Egypt. Anthropology Today 27: 13.

Shavit Y, Muller W (2000) Vocational education: where diversion and where safety net? European Societies 2: 29-50.

Singerman D (2007) The Economic Imperatives of Marriage: Emerging Practices and Identities among Youth in the Middle East. Working Paper 6, The Middle East Youth Initiative. Dubai: Wolfensohn Center for Development.

Singerman D (2013) Youth, gender and dignity in the Egyptian uprising. Journal of Middle East Women's Studies 9: 1-27.

Sika N (2012) Youth political engagement in Egypt: from abstention to uprising. British Journal of Middle Eastern Studies 39: 181-199.

Skalli LH (2013) Youth, media and the politics of change in North Africa: negotiating identities, spaces and power. Middle East Journal of Culture and Communication 6: 5-14.

Staeheli L, Nagel CR (2012) Whose awakening is it? Youth and the geopolitics of civic engagement in the "Arab Awakening". European Urban and Regional Studies 20: 115-119. 
Steavenson W (2015) Circling the Square: Stories from the Egyptian Revolution. London: Grants Publications.

Sueur JD Le (2010) Between Terror and Democracy: Algeria since 1989. London: Zed books.

The Guardian/London School of Economics (2012) Reading the Riots: Investigating England's Summer of Disorder. London: London School of Economics.

Tholen J (2014) Employment, Education and Social Inclusion: Algeria, Morocco, Tunisia, Egypt and Lebanon, SAHWA BP/01-2014. Barcelona: CIDOB.

Tugal C (2015) Religious politics, hegemony, and the market economy: parties in the making of Turkey's liberal-conservative bloc and Egypt's diffuse Islamization. In C de Leon, M Desai, C Tugal (Eds) Building Blocs: How Parties Organize Society, 87-122. Stanford: Stanford University Press.

Vandewalle D (2012) A History of Modern Libya. Cambridge: Cambridge University Press. 
